\title{
EFFECTS OF PHYSOSTIGMINE ON BRAIN ACETYLCHOLINE CONTENT AND RELEASE* +
}

\author{
A. Bartolini, $\ddagger$ Rosalia Bartolini $\S$ and E. F. Domino \\ Neuropsychopharmacology Research Program, Department of Pharmacology, University of Michigan, \\ Ann Arbor, Michigan 48104
}

(Accepted 5 June 1972)

\begin{abstract}
Summary-The content and release of acetylcholine ( $\mathrm{ACh}$ ) from cat brain and $\mathrm{ACh}$ content of rat brain was measured using the frog rectus and leech muscle bioassays before and after physostigmine $100 \mu \mathrm{g} / \mathrm{kg}$ i.v. or i.p. The drug elevates steady state levels of brain ACh of awake animals especially in the neocortex, caudate nucleus and hippocampus but much less so in the lateral geniculate and superior colliculus. Physostigmine was shown to produce neocortical release of ACh through a subcortical mechanism in brainstem transected cats and to decrease ACh neocortical content in pentobarbital anesthetized cats and rats. The neocortical release of ACh seems to be mediated primarily through a subcortical brain mechanism which is activated by physostigmine. It is postulated that the ascending reticular formation is involved. Local application of scopolamine $(1 \mu \mathrm{g} / \mathrm{ml})$ into the collecting cup did not antagonize the effects of $100 \mu \mathrm{g} / \mathrm{kg}$ of physostigmine i.v. as much as $1 \mathrm{mg} / \mathrm{kg}$ of scopolamine i.v. On the other hand, $2 \mathrm{mg} / \mathrm{kg}$ of mecamylamine given i.v. not only did not antagonize physostigmine-induced neocortical release of $\mathrm{ACh}$, but seemed to enhance it. The results indicate a complex action of physostigmine on the cholinergic system of the brain.
\end{abstract}

It is well known that physostigmine increases total brain acetylcholine (ACh) content (Pazzagli and Pepeu, 1964; Rosecrans, Dren and Domino, 1968; Malpica, Jurupe and CAMPOS, 1970). However, the per cent increase in regional brain $A C h$ varies markedly (Fischer, Westermann and Oelssner, 1969; Megazzini, Bernardi and Ballotti, 1965). As might be expected on the basis of its well known anticholinesterase properties, physostigmine increases "free" brain ACh (BEANI et al., 1969; Crossland and Slater, 1968). A functional role for this increase in "free" ACh is suggested by the observation that physostigmine produces low voltage, desynchronized EEG activity (BRADLEY and ELKES, 1953; LonGo and Sir vestrini, 1957; Yamamoto and DOMINo, 1967). Under certain conditions physostigmine induces rapid eye movement (REM) sleep (CARRUYO and DOMINO, 1970; Domino, Yamamoto and Dren, 1968; Karczmar, Longo and ScotTi DE Carolis, 1970).

Although there is not a $1: 1$ relation between EEG activation, ACh content and release, under most circumstances the correlation is quite high. During EEG activation the content of $\mathrm{ACh}$ is reduced and its cerebral release increased, with the reverse situation during EEG

*Supported in part by grant MH-11846, USPHS.

†Preliminary results were presented at the joint meeting of the Italian Pharmacological Society and the Belgian Physiological and Pharmacological Society held in Gand, September 1971.

$\ddagger$ Italo-American exchange research fellow from the Department of Pharmacology, University of Florence.

Awarded a grant under the mutual education and cultural exchange Fulbright Hays Act and the Italian National Council of Researches.

\$Italo-American exchange laboratory technologist from the Department of Pharmacology, University of Florence. 
synchronization (Tobias, Lipion and LePinat, 1946; Richiter and Crossland, 1949; Pepeu and Mantegazzini, 1964; Macintosh and Oborin, 1953; Mitchell, 1963; Bartolini and PePeU, 1967; Celesia and JAsPer, 1966). During REM sleep cortical ACh release is as great as during wakefulness; in contrast, $\mathrm{ACh}$ release is reduced during non-rapid eye movement (NREM) sleep (JASPER and TESSIER, 1971). The effects induced by physostigmine, atropine and scopolamine are the best known exceptions to the relation of EEG-ACh content and release.

Physostigmine appears to have actions other than its well known anticholinesterase effects. It releases ACh from isolated guinea pig atria (BARTOLINI and OCELlo, 1965) and rat brain slices (BERTELS-MEeuws and POLAK, 1968) and has possible direct neuronal agonistic effects (Bradley, Dhawan and Wolstencroft, 1966). Physostigmine has biphasic effects on pentobarbital sleeping time depending upon dose (BARNES and MEYERS, 1964; Davis, King and BabBini, 1971; KalyanPur and PraSAD, 1967).

Inasmuch as the cholinergic agonist and antagonist, physostigmine and scopolamine, are the best known exceptions to the relation between EEG and cortical ACh content and release, we decided to clarify their mechanisms of action. It was decided that it would be of value to compare in the cat the effects of physostigmine on regional brain ACh content with its effects on cortical release with and without pentobarbital. The cat was chosen because of its brain size. In addition, the effects of physostigmine and pentobarbital were studied on rat brain $\mathrm{ACh}$ because of the short times possible for brain removal and subsequent $\mathrm{ACh}$ extraction.

\section{ACh release}

\section{METHODS}

Fifteen mongrel adult cats of both sexes were used. All surgery was performed under halothane-air anaesthesia. Suitable cannulae were inserted in the trachea, vein, artery for adequate ventilation, i.v. injections and recording arterial BP. The animal's head was placed in a stereotaxic apparatus. In order to avoid the complications of anaesthesia during the experiment, a brainstem transection was made by means of a stereotaxically oriented spatula. Most of the cats were transected at a midpontine pretrigeminal level but some were transected at a collicular prepontine level. The atlanto-occipital membrane was opened to allow free drainage of the cerebrospinal fluid. Shortly following transection, the skull was opened over a large part of the frontoparietal area. The cats were allowed to recover from the halothane anaesthesia for $3 \mathrm{hr}$. During this interval they resumed spontaneous respiration. Body temperature was maintained with a heating pad as close to $37^{\circ} \mathrm{C}$ as possible, as monitored by a rectal probe. Cats in which either brain hemorrhage or edema occurred were discarded. Blood pressure was recorded from the femoral artery by means of a Statham pressure transducer and recorded on a polygraph.

The collecting cups were constructed according to Mitchell (1963). After opening the dura, a perspex cylinder covering $0.76 \mathrm{~cm}^{2}$ of the cortex was lowered onto the sensorimotor and its posterior association area with the aid of an adjustable electrode carrier. The cylinder was filled with $0.7 \mathrm{ml}$ of a Ringer's medium containing (concentration in $\mathrm{g} / \mathrm{l}$.) $\mathrm{NaCl} 9 \cdot 0 ; \mathrm{KCl} 0.42 ; \mathrm{CaCl}_{2} 0.24 ; \mathrm{NaHCO}_{3} 0.5 ;$ glucose 1.0 and physostigmine sulphate 0.1 . Every $10 \mathrm{~min}$ the solution was aspirated from the collecting cup and bioassayed immediately for ACh using the dorsal muscle of the leech according to the, method of MuRNaGHAN (1958). The muscle was suspended in a $2 \mathrm{ml}$ bath. The upper end of the muscle was connected to a small mirror which reflected a beam of light onto a graduated scale approximately $5 \mathrm{ft}$ 
away on the wall allowing a 200 fold magnification. The samples collected from the cups were diluted with distilled water ( 1.0 volume diluted to 1.4 volumes) to achieve isotonicity with the leech Ringer solution. The samples were then compared with standard solutions of $\mathrm{ACh} \mathrm{HCl}$ containing the same concentration of physostigmine. In order to assure that maximal cholinesterase inhibition had occurred in the area of the cortex beneath the cup, samples from the first four 10-min intervals were not assayed. Evidence that the substance released into the cup was either $\mathrm{ACh}$ or some very similar choline ester has been given previously (MitChell, 1963; SzERB, 1963; BARTOLINI and PEPEU, 1967). The electrical activity of the cerebral cortex was recorded by means of screw electrodes inserted into the skull and a silver ball electrode placed inside the collecting cup. In all experiments the drugs were injected through a polyethylene cannula inserted into the femoral vein. Following termination of the experiment, the brainstem transection was determined macroscopically.

\section{ACh content}

(A) Fifteen adult cats of both sexes were divided into three groups. The first group received saline, the second $40 \mathrm{mg} / \mathrm{kg}$ of pentobarbital together with $100 \mu \mathrm{g} / \mathrm{kg}$ of physostigmine and the third group $40 \mathrm{mg} / \mathrm{kg}$ of pentobarbital alone, all i.p. Within a few minutes the cats receiving pentobarbital were comatose. Those also receiving physostigmine showed cholinergic symptoms such as diarrhea. Fifteen minutes after injection, the cats were sacrificed by decapitation utilizing a large pneumatic guillotine. The skull was quickly sawn midsagitally and the brain removed and placed on ice. From each brain 10 samples were isolated. These included the right and left lateral geniculate, superior colliculus, caudate nucleus, hippocampus and primary visual cortex. The samples were weighed on a RollerSmith torsion balance and homogenized in a tube with a chilled mixture of $0.2 \%$ acetic acid in $95 \%$ ethyl alcohol. A maximum time of 7 min elapsed between decapitation and the onset of homogenization. ACh was extracted according to the method of STONE (1955) and Crossland (1961) and bioassayed the same day, as described previously. That the extracted substance was ACh or a similar choline ester was established by the following: (1) the muscle did not respond to the extract after treatment with $d$-tubocurarine hydrochloride $\left(3 \times 10^{-6} \mathrm{~g} / \mathrm{ml}\right)$, (2) the substance was stable in an acid medium, (3) boiling in an alkaline medium abolished its ability to elicit a muscle response.

(B) Fifty four Holtzman male albino rats weighing about $250 \mathrm{~g}$ were divided into three groups. Each group received the same treatment as described previously for the three groups of cats. Fifteen minutes after injection the rats were decapitated by guillotine. In one series, the entire brain (excluding cerebellum, olfactory lobes and pituitary) and in the other a large portion of the cerebral cortices of both hemispheres were removed quickly and total ACh was extracted by the method of StOnE (1955) and Crossland (1961). The ACh-like activity of the extracts was bioassayed on the isolated frog (Rana pipiens) rectus abdominis muscle preparation. As suggested by FELDBERG (1945), ACh standards were prepared in alkali-inactivated extracts to allow for the presence of sensitizing factors in the brain tissue.

\section{RESULTS}

\section{Effects of physostigmine and pentobarbital on acetylcholine content}

As shown in Table 1, pentobarbital in a dose of $40 \mathrm{mg} / \mathrm{kg}$ i.p. produced a highly significant increase of ACh in the visual cortex, caudate nucleus and hippocampus of cats. When pentobarbital was administered together with $100 \mu \mathrm{g} / \mathrm{kg}$ of physostigmine, no further 
Table 1. Effects of physostigmine and pentobarbital on acetylcholine content of some cerebral areas of the cat

\begin{tabular}{|c|c|c|c|c|c|}
\hline Treatment & $\begin{array}{l}\text { Lateral } \\
\text { geniculate }\end{array}$ & $\begin{array}{l}\text { Superior } \\
\text { colliculus }\end{array}$ & $\begin{array}{l}\text { Visual } \\
\text { cortex }\end{array}$ & $\begin{array}{c}\text { Caudate } \\
\text { nucleus }\end{array}$ & Hippocampus \\
\hline Saline & $\begin{array}{c}(6) \\
8 \cdot 7 \pm 1 \cdot 3\end{array}$ & $\begin{array}{c}(6) \\
7 \cdot 8 \pm 0 \cdot 9\end{array}$ & $\begin{array}{c}(5) \\
1 \cdot 2 \pm 0 \cdot 1\end{array}$ & $\begin{array}{c}(6) \\
4 \cdot 2 \pm 0 \cdot 3\end{array}$ & $\begin{array}{c}(7) \\
2 \cdot 6 \pm 0 \cdot 3\end{array}$ \\
\hline $\begin{array}{l}\text { Pentobarbital } \\
40 \mathrm{mg} / \mathrm{kg} \text { i.p. }\end{array}$ & $\begin{array}{c}(5) \\
9 \cdot 7 \pm 0 \cdot 9\end{array}$ & $\begin{array}{c}(8) \\
7 \cdot 8 \pm 1 \cdot 1\end{array}$ & $\begin{array}{c}(6) \\
2 \cdot 9 \pm 0 \cdot 4\end{array}$ & $\begin{array}{c}(8) \\
6 \cdot 2+0 \cdot 3\end{array}$ & $\begin{array}{c}(8) \\
3 \cdot 2 \pm 0 \cdot 2\end{array}$ \\
\hline $\begin{array}{l}\text { Pentobarbital } \\
40 \mathrm{mg} / \mathrm{kg} \text { i.p. } \\
\text { Physostigmine } \\
100 \mu \mathrm{g} / \mathrm{kg} \text { i.p. }\end{array}$ & $\begin{array}{c}(13) \\
9 \cdot 8 \pm 1 \cdot 0\end{array}$ & $\begin{array}{c}(13) \\
8 \cdot 1 \pm 1 \cdot 4\end{array}$ & $\begin{array}{c}(12) \\
1 \cdot 8 \pm 0 \cdot 2\end{array}$ & $\begin{array}{c}(13) \\
6 \cdot 1 \pm 0.5\end{array}$ & $\begin{array}{c}(6) \\
3 \cdot 4 \pm 0.6\end{array}$ \\
\hline
\end{tabular}

The number of experiments are given in the parentheses. Data expressed as mean \pm S.E. in $\mu \mathrm{g} / \mathrm{g}$ wet weight. Cats were sacrificed 15 min after i.p. injection.

statistically significant $\mathrm{ACh}$ increase occurred in the caudate and hippocampus. What is more surprising, in the visual cortex a significant $\mathrm{ACh}$ decrease was obtained in comparison to pentobarbital alone. In addition, neither pentobarbital alone nor pentobarbital plus physostigmine changed the ACh levels of lateral geniculate body and superior colliculus. Because of these unexpected findings, some of the experiments were repeated in rats. In male Holtzman rats the cortical ACh was also significantly lower after pentobarbital with physostigmine than after pentobarbital alone (Table 2). However, the cortical ACh content after pentobarbital plus physostigmine was greater than after saline. In contrast, the ACh content of whole rat brain was almost the same with pentobarbital plus physostigmine as with pentobarbital alone. Both treated groups had a brain ACh content higher than the saline control group, as expected. The results on whole rat brain are therefore similar to those on cat caudate nucleus and hippocampus.

Table 2. Effects of physostigmine and pentobarbital on acetylcholine content of the neocortex and whole brain of rats

\begin{tabular}{|c|c|c|c|c|}
\hline Treatment & $\mathbf{N}$ & $\begin{array}{l}\text { Cerebral } \\
\text { cortex }\end{array}$ & $\mathbf{N}$ & $\begin{array}{l}\text { Whole } \\
\text { brain }\end{array}$ \\
\hline Saline & 8 & $\begin{array}{c}3 \cdot 7 \pm 0 \cdot 1 \\
\begin{array}{c}\uparrow \\
<\end{array} \\
\quad \downarrow-01 \\
\end{array}$ & 8 & $\begin{array}{c}3.4 \pm 0.1 \\
\uparrow \\
P<0.01 \\
\downarrow\end{array}$ \\
\hline Pentobarbital $40 \mathrm{mg} / \mathrm{kg}$ i.p. & 7 & $\begin{array}{c}5.6+0.2 \\
\uparrow \\
P<0.05 \\
\downarrow\end{array}$ & 12 & $\begin{array}{c}4 \cdot 4 \underset{\uparrow}{ \pm} 0 \cdot 2 \\
\text { N.S. } \\
\downarrow\end{array}$ \\
\hline $\begin{array}{l}\text { Pentobarbital } 40 \mathrm{mg} / \mathrm{kg} \text { i.p. } \\
\text { Physostigmine } 100 \mu \mathrm{g} / \mathrm{kg} \text { i.p. }\end{array}$ & 7 & $4 \cdot 7 \pm 0 \cdot 3$ & 12 & $4 \cdot 8 \pm 0 \cdot 2$ \\
\hline
\end{tabular}

Rats were sacrificed $15 \mathrm{~min}$ after the i.p. injection. The $P$ values for group comparison $t$-tests are given hetween various groups as indicated. The data are expressed as the mean \pm S.E. in $\mu \mathrm{g} / \mathrm{g}$ wet weight. 
Effect of physostigmine on cortical ACh release

When $100 \mu \mathrm{g} / \mathrm{kg}$ of physostigmine was injected i.v. in brainstem transected cats an obvious mydriasis occurred, irrespective of the electrocortical activity. An obvious slight EEG activation was seen in those cats with a previously synchronized EEG. In Figure 1 three release

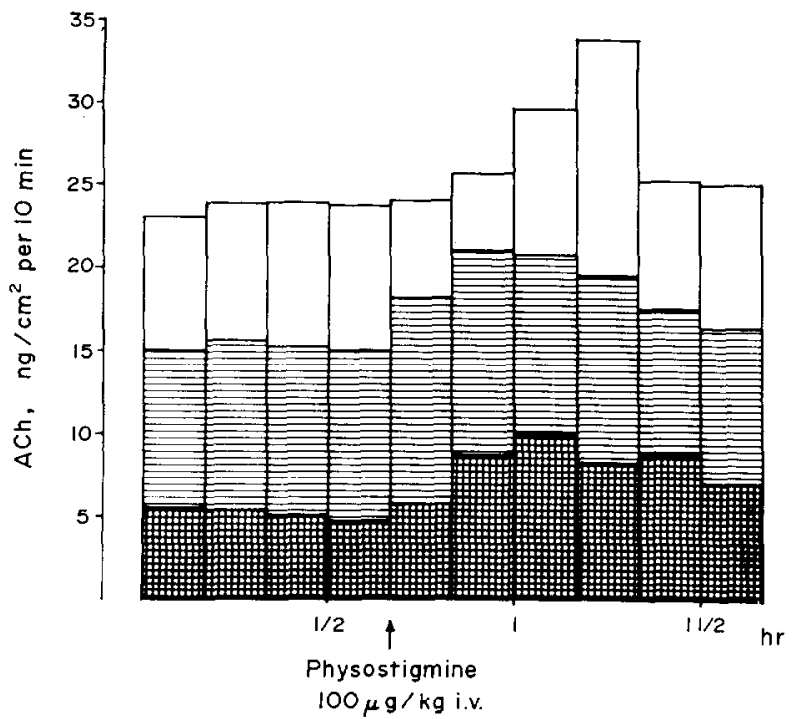

Fig. 1. Effect of physostigmine on cortical acetylcholine release as a function of basal output. The data are expressed in the form of three different superimposed bar graphs as shown. The per cent release varics with the basal level. Note with small basal outputs the per cent release is greater than with high basal output levels. However, in all cases physostigmine in a dose of $100 \mu \mathrm{g} / \mathrm{kg}$ i.v. increased the release of ACh. This effect was maximal approximately $30 \mathrm{~min}$ after administration. It should be noted that in this and all subsequent experiments physostigmine was also present in the collecting cup in a concentration of $1 \times 10^{-4} \mathrm{~g} / \mathrm{ml}$.

experiments on different cats are illustrated. The three animals had markedly different basal ACh release levels and were selected to show the ability of physostigmine to increase cortical ACh output. It is clear, however, that the effect of physostigmine is inversely proportional to the basal release level. The mean per cent increase of $\mathrm{ACh}$ output due to physostigmine was $59 \%$ in 4 experiments (Table 3 ).

\section{Effect of locally applied scopolamine on physostigmine evoked ACh release}

Physostigmine retained its ability to release ACh even after scopolamine $\mathrm{HBr}$ $\left(1 \times 10^{-6} \mathrm{~g} / \mathrm{ml}\right)$ was placed in the collecting cup (Fig. 2). The high basal release level caused by scopolamine is consistent with the well known stimulating effect of anticholinergic drugs on the ACh output. Local cortical application of scopolamine did not change the EEG pattern. The mean per cent increase of ACh release due to physostigmine injection after locally applied scopolamine was $65 \%$ in 3 experiments (Table 3 ).

\section{Effect of intravenous scopolamine pretreatment on physostigmine evoked ACh release}

As expected, scopolamine $\mathrm{HBr}$ in a dose of $1 \mathrm{mg} / \mathrm{kg}$ i.v. markedly increased the basal cortical ACh release. Physostigmine in a dose of $100 \mu \mathrm{g} / \mathrm{kg}$ i.v. was administered $40 \mathrm{~min}$ after scopolamine injection when the evoked ACh release was maximal. After i.v. scopolamine 


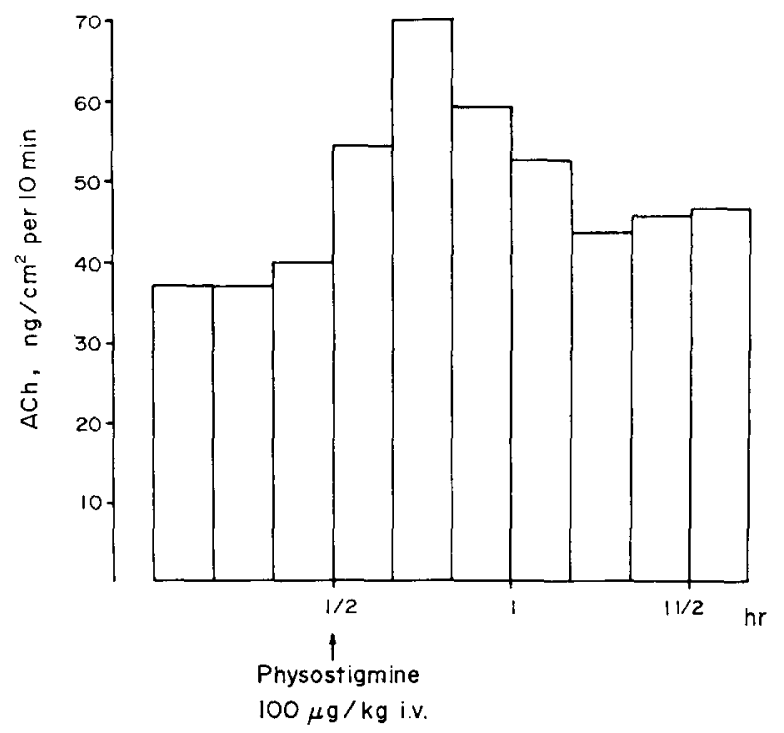

Fig. 2. Lack of effect of.locally applied scopolamine on physostigmine evoked acetylcholine release from the cat cerebral cortex. Local application of scopolamine in a concentration of $1 \mu \mathrm{g} / \mathrm{ml}$ resulted in a high basal level of release of ACh from the cerebral cortex. However, this did not prevent the enhanced release of ACh following $100 \mu \mathrm{g} / \mathrm{kg}$ i.v. physostigmine.

Table 3. Effect of scopolamine and mecamylamine on physostigmine evoked cortical acetylcholine release of brainstem transected cats

\begin{tabular}{|c|c|c|c|}
\hline \multirow[b]{2}{*}{ Pretreatment } & \multicolumn{2}{|c|}{$\begin{array}{l}\text { Acetylcholine output } \\
\left(\mathrm{ng} / \mathrm{cm}^{2} \text { per } 10 \mathrm{~min}\right)\end{array}$} & \multirow[b]{2}{*}{$\begin{array}{c}\% \\
\text { variation }\end{array}$} \\
\hline & $\begin{array}{c}\text { Before } \\
\text { physostigmine }\end{array}$ & $\begin{array}{c}\text { Maximum after } \\
\text { physostigmine } \\
100 \mu \mathrm{g} / \mathrm{kg} \text { i.v. }\end{array}$ & \\
\hline Saline & $\begin{array}{r}5 \cdot 5 \\
4 \cdot 8 \\
23 \cdot 7 \\
15 \cdot 0 \\
\end{array}$ & $\begin{array}{r}8 \cdot 2 \\
9 \cdot 9 \\
33 \cdot 7 \\
21 \cdot 0 \\
\end{array}$ & $\begin{array}{r}+49 \% \\
+106 \% \\
+42 \% \\
+40 \% \\
\end{array}$ \\
\hline Mean & $\overline{12 \cdot 2}$ & $\overline{18 \cdot 2}$ & $+59 \%$ \\
\hline $\begin{array}{l}\text { Scopolamine } \mathrm{HBr} \\
1 \mu \mathrm{g} / \mathrm{ml} \\
\text { locally applied }\end{array}$ & $\begin{array}{l}59 \cdot 7 \\
39 \cdot 9 \\
42 \cdot 9\end{array}$ & $\begin{array}{l}87 \cdot 0 \\
70 \cdot 1 \\
74 \cdot 9\end{array}$ & $\begin{array}{l}+46 \% \\
+76 \% \\
+75 \% \\
\end{array}$ \\
\hline Mean & $\overline{47 \cdot 5}$ & $\overline{77 \cdot 3}$ & $+\overline{65 \%}$ \\
\hline $\begin{array}{l}\text { Scopolamine } \mathrm{HBr} \\
1 \mathrm{mg} / \mathrm{kg} \text { i.v. }\end{array}$ & $\begin{array}{l}73 \cdot 8 \\
44 \cdot 5 \\
50 \cdot 5 \\
24 \cdot 4\end{array}$ & $\begin{array}{l}81 \cdot 9 \\
57 \cdot 8 \\
56 \cdot 4 \\
40 \cdot 4\end{array}$ & $\begin{array}{l}+11 \% \\
+29 \% \\
+12 \% \\
+65 \%\end{array}$ \\
\hline Mean & $\overline{48 \cdot 3}$ & $59 \cdot 1$ & $+29 \%$ \\
\hline $\begin{array}{l}\text { Mecamylamine } \mathrm{HCl} \\
2 \mathrm{mg} / \mathrm{kg} \text { i.v. }\end{array}$ & $\begin{array}{l}18 \cdot 8 \\
14 \cdot 0\end{array}$ & $\begin{array}{l}37 \cdot 9 \\
26 \cdot 1\end{array}$ & $\begin{array}{l}+101 \% \\
+86 \%\end{array}$ \\
\hline Mean & $\overline{16 \cdot 4}$ & $\overrightarrow{32 \cdot 0}$ & $+93 \%$ \\
\hline
\end{tabular}


pretreatment the physostigmine effect was markedly reduced. The effects are illustrated in Figure 3 of a bar graph of one typical experiment. The mean per cent increase of ACh release due to physostigmine after scopolamine pretreatment was $29 \%$ in 4 experiments (Table 3 ). Physostigmine given i.v. did not produce any obvious change in the scopolamine-induced slow wave EEG pattern.

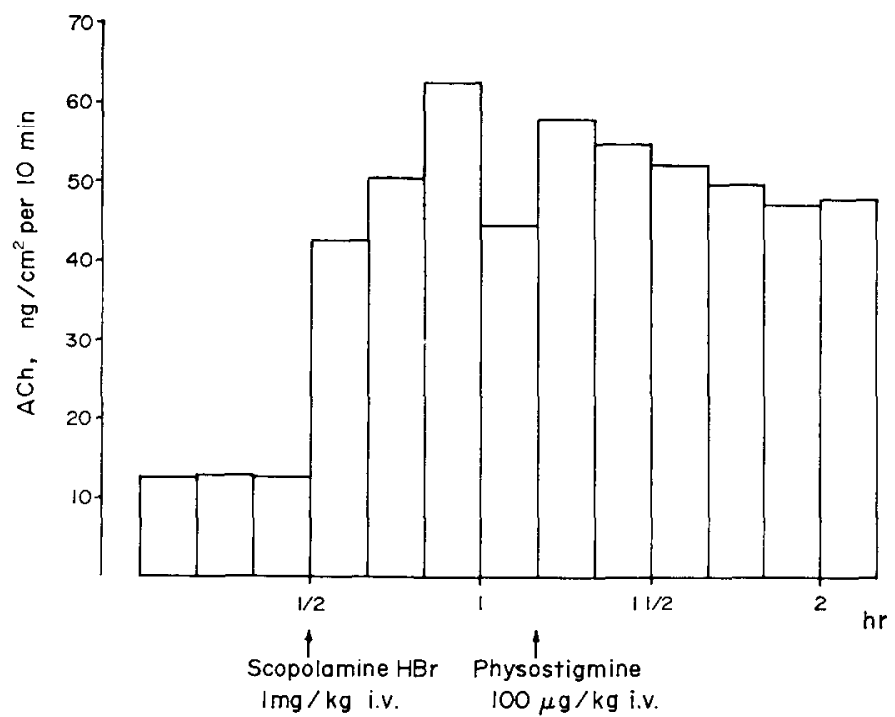

Fig. 3. Antagonistic effect of i.v. scopolamine on physostigmine-evoked acetylcholine release from the cat cerebral cortex. Scopolamine in a dose of $1 \mathrm{mg} / \mathrm{kg}$ i.v. caused an increase in $\mathrm{ACh}$ release. However, physostigmine administration after scopolamine caused only a slight increase in $\mathrm{ACh}$ release, indicating that scopolamine partially antagonized the effects of physostigmine.

Note that the percentage of release induced by physostigmine was relatively small.

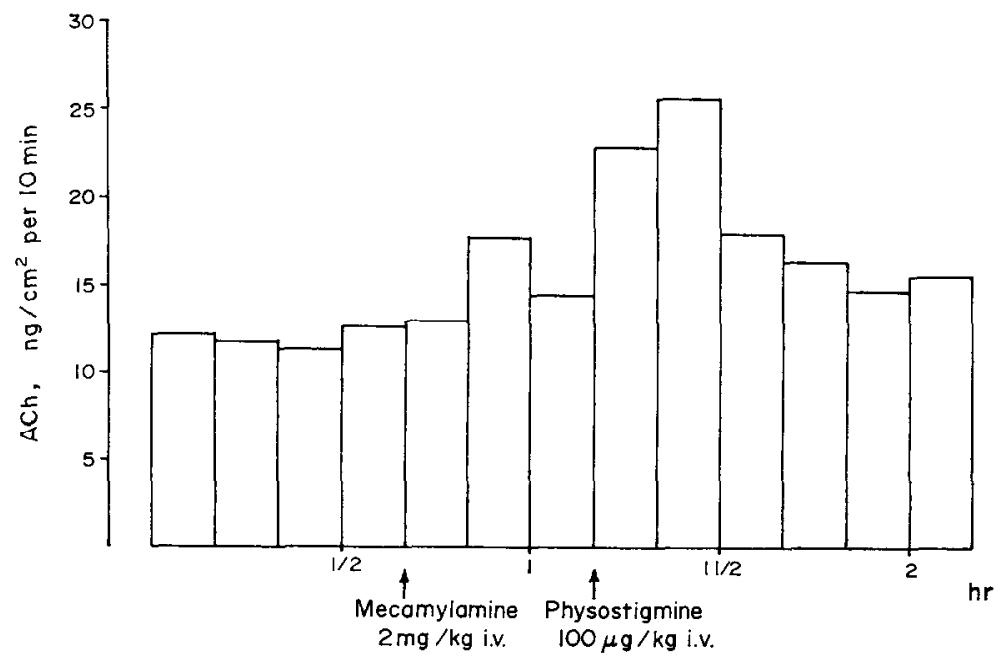

Fig. 4. Failure of mecamylamine to block physostigmine-evoked acetylcholine release from the cat cerebral cortex. Mecamylamine did not block physostigmine-induced release of ACh. In fact, on a percentage basis, the release of $\mathrm{ACh}$ induced by physostigmine was somewhat greater than would be expected from normal basal release levels. Mecamylamine was given in dose of $2 \mathrm{mg} / \mathrm{kg}$ and physostigmine in a dose of $100 \mu \mathrm{g} / \mathrm{kg} \mathrm{i.v.} \mathrm{at} \mathrm{the} \mathrm{times} \mathrm{noted.}$ 


\section{Effect of mecamylamine pretreatment on physostigmine evoked ACh release}

Mecamylamine in a dose of $2 \mathrm{mg} / \mathrm{kg}$ i.v. not only did not antagonize the physostigmine effect but it seemed to potentiate it. Moreover, mecamylamine itself slightly increased the basal release of $\mathrm{ACh}$. These effects are illustrated in Figure 4 which depicts an experiment in which mecamylamine was injected $30 \mathrm{~min}$ before physostigmine. The EEG tracing was not significantly changed after i.v. mecamylamine. Physostigmine still produced FEG activation in those animals that had a synchronized EEG. The mean per cent increase in cortical release of $\mathrm{ACh}$ due to physostigmine after mecamylamine pretreatment was $93 \%$ (Table 3 ).

\section{DISCUSSION}

There are two major criticisms to research of this type. The first relates to the fact that dissections of cats' brains were done on ice and that up to $7 \mathrm{~min}$ were required between dissection and denaturation of brain enzymes. One would expect obvious differences in regional brain temperature, depending upon contact with the ice and therefore different rates of synthesis and degradation of free and bound $\mathrm{ACh}$. Thus, the values of regional $\mathrm{ACh}$ are not a measure of true ACh content in vivo. The same criticism would apply to the rat brain, but the total time from decapitation to protein denaturation would be much less. Since the order of dissection was exactly the same between the control and drug-treated series, drug differences from control would be relative, but still valid. We feel such an experimental approach, while far from ideal, is still acceptable. Secondly, there is a maximal rate of ACh release possible from the neocortex. Calculations based on the percent increase in $\mathrm{ACh}$ release following physostigmine, with and without prior treatment with scopolamine, can be misleading. However, when scopolamine was applied locally to the cortex the mean rate of ACh release was $47.5 \mathrm{ng} / \mathrm{cm}^{2}$ per $10 \mathrm{~min}$. This was not the maximal rate of ACh release since physostigmine given i.v. increased $\mathrm{ACh}$ release up to $77.3 \mathrm{ng} / \mathrm{cm}^{2}$ per $10 \mathrm{~min}$ or a $65 \%$ increase. When scopolamine was given i.v. the mean ACh release was $48 \cdot 3 \mathrm{ng} / \mathrm{cm}^{2} / 10 \mathrm{~min}$ and after physostigmine this was increased to $59 \cdot 1 \mathrm{ng} / \mathrm{cm}^{2}$ per $10 \mathrm{~min}$ or only a $29 \%$ increase.

In both the rat and cat pentobarbital anaesthesia elevated cerebral cortical levels of $\mathrm{ACh}$. In these barbiturate-anaesthetized animals physostigmine in moderate doses reduced significantly the cortical ACh levels compared to pentobarbital alone. Compared to saline the cortical levels of ACh were still significantly elevated. As is true of ACh itself, physostigmine has biphasic dose-dependent actions on the autonomic and CNS activity as reflected in its effects on respiration and other subcortical functions. The effect is characterized by stimulation or facilitation in low concentrations, succeeded by inhibition or paralysis at higher concentrations (PATON and PERRY, 1953; KOELLE, 1970). Since the ACh content of the neocortex is lower during EEG activation than synchronization (PEPEU and MANTEGAZZINI, 1964), our observation of a decrease in cortical ACh content of pentobarbital anaesthetized animals induced by physostigmine is in good agreement with its arousal properties in low to moderate doses (BradleY and ElKes, 1953; LONGO and Silvestrini, 1957; Yamamoto and Domino, 1967). All previous data showing that physostigmine increases brain ACh content were obtained in awake animals already having a low brain ACh content. Under such experimental conditions it is impossible, considering physostigmine-induced cholinesterase inhibition, to reveal a decreasing effect of physostigmine on brain ACh content.

The finding that physostigmine reduces slightly the elevated cortical levels of $\mathrm{ACh}$ in pentobarbital anaesthetized animals is, of course, in complete agreement with the data of others that physostigmine alone elevated brain ACh above control levels (BEANI et al., 1969; 
Crossland and Slater, 1968; Fischer et al., 1969; MAlPICA et al., 1970; MegazZiNi et al., 1965 ; ROSECRANS et al., 1968).

The ability of physostigmine to reduce cortical ACh content probably is due to its ACh releasing property. Physostigmine, $100 \mu \mathrm{g} / \mathrm{kg}$ i.v., in fact always increased cortical ACh output either in EEG activated or synchronized cats. The ACh-induced release, however, was proportionally greater in cats previously having EEG slow waves. This observation together with the fact that physostigmine was present in the collecting cup throughout the experiment, allows one to suggest that the increased $\mathrm{ACh}$ release following physostigmine was concomitant to cortical EEG activation. Celesia and JASPer (1966) and BAr Tolini and PePeU (1967) have demonstrated that an activated EEG pattern is associated with a high release of $\mathrm{ACh}$ from the neocortex and a synchronized EEG pattern with a low ACh release.

BARTOLINI and OCELlo (1965) showed that physostigmine increased within the first few minutes of contact the basal release of ACh from isolated guinea pig's atria beating in vitro. This effect seemed to be unrelated to the physostigmine-induced cholinesterase inhibition. BERTELS-MEEUWS and POLAK (1968) subsequently showed that physostigmine decreases ACh content and increases ACh release from rat brain cortex slices incubated in a high potassium medium in vitro and pretreated with the cholinesterase inhibitor Soman. Since physostigmine in our experiments was already present in very high concentrations $\left(1 \times 10^{-4} \mathrm{~g} / \mathrm{ml}\right.$ of physostigmine sulphate) in the collecting cup before its i.v. injection, it is possible to rule out a direct effect of physostigmine on the cerebral cortex. It is also possible to rule out that the enhanced $\mathrm{ACh}$ release is due to a greater inhibition of cortical cholinesterase for it is probably already maximally inhibited. It is important to stress that we have found that i.v. scopolamine in contrast to local cortically applied scopolamine blocked or markedly reduced the physostigmine-evoked ACh release. It appears, therefore, that physostigmine acts on subcortical structures because only systemically administered scopolamine blocked its effect and because physostigmine was already locally present. If the i.v. physostigmine effect was the result of a greater inhibition of cortical cholinesterases it would be very difficult to explain either the i.v. scopolamine blocking action or the cortical ACh content decrease in pentobarbital treated cats and rats. The simplest explanation of the phenomenon observed is that i.v. physostigmine increases the $\mathrm{ACh}$ available at subcortical receptors, especially in the reticular formation or its ascending elements either through a direct ACh releasing action or through cholinesterase inhibition. The $\mathrm{ACh}$ evoked stimulation of the ascending reticular formation could be the cause either of $E E G$ arousal, cortical $A C h$ release and depletion. Several experiments support this hypothesis. These include: (A) Microelectrophoretic studies have shown that reticular neurons are excited by $\mathrm{ACh}$ and by physostigmine (Bradley et al., 1966; SAlmoiraghi and Steiner, 1963). Moreover, atropine specifically blocks the actions of $\mathrm{ACh}$, particularly the excitatory effects upon the response of AChsensitive reticular neurons (BRADLEY et al., 1966). (B) SHUTE and LEWIS (1963, 1967) have studied the histochemical distribution of acetylcholinesterase in the rat brain. They have described cholinergic pathways from the ventral tegmental area and substantia nigra to the neocortex. (C) Evoked cortical potentials duc to electrical stimulation of the midline and medial regions of the midbrain tegmentum (reticulocortical potentials) are totally blocked by i.v. administration of muscarinic cholinergic antagonists, but not by their cortical application. Furthermore, the i.v. administration of anticholinesterase agents markedly potentiates the amplitude of reticulocortical potentials (ILYUTCHENOK and ZINEVICH, 1970). (D) An EEG activation response is elicited either by direct electrical stimulation of the mesencephalic reticular formation or by cholinergic agonists such as $\mathrm{ACh}$, physostigmine, 
arecoline, pilocarpine and oxotremorine (LONGO and SILVESTRINI, 1957; EVERETT, 1964; Yамамото and Domino, 1967). Furthermore, muscarinic cholinergic antagonists like atropine, but not nicotinic cholinergic antagonists like mecamylamine, block EEG desynchronization produced by muscarinic agonists including physostigmine (CELESIA and JASPER, 1966; Everett, 1964; YAMAmoto and Domino, 1967). Similarly, our experiments show that systemically administered scopolamine, but not mecamylamine, markedly reduces the physostigmine-evoked $\mathrm{ACh}$ release from the neocortex.

CELFSIA and JASPER (1966) have shown that local cortical application of neostigmine to sleeping animals causes local desynchronized activation followed by local epileptiform discharge without changing the rate of ACh liberation. Again, this data indirectly suggests the necessity for the anticholinesterase agents to stimulate subcortical structures in order to obtain both EEG activation and the increase of cortical ACh release.

MEGAZZINI et al. (1965) have shown that choline acetylase activity is significantly greater in the neocortex and cerebellar vermis of guinea-pigs treated for one week with physostigmine, $100 \mu \mathrm{g} / \mathrm{kg}$ i.p. Our results help to explain Megazzini's data by showing that the increased choline acetylase activity is probably induced because physostigmine increases cortical ACh release. Finally, YamamoTo and Domino (1967) found that i.v. mecamylamine not only did not decrease physostigmine-evoked EEG activation but significantly increased its duration. Similarly, our data show that mecamylamine potentiated physostigmine evoked $\mathrm{ACh}$ release from the neocortex.

In conclusion, the present results have clarified the apparent contradiction between the different actions of physostigmine to alter brain $\mathrm{ACh}$ content as well as causing EEG activation. Furthermore, a subcortical mechanism seems to be involved.

Acknowledgements-The authors would like to acknowledge the efforts of Miss ANN WILson in performing some of the ACh assays.

\section{REFFRFNCFS}

Barnes, C. D. and Meyers, F. H. (1964). Eserine and amphetamine: Interactive effects on sleeping time in mice. Science 144: 1221-1222.

Bartolin, A. and OCELlo, R. (1965). Liberazione di acetilcolina da atri isolati di cavia in presenza di mipafox e di eserina. Boll. Soc. ital. Biol. sper. 41 : 1480-1483.

Bartolini, A. and Pepeu, G. (1967), Investigations into the acetylcholine output from the cerebral cortex of the cat in the presence of hyoscine. Br. J. Pharmac. Chemother. 31: 66-73.

Beani, L., Biancil, C., Megazzini, P., Ballotti, L. and Bernardi, G. (1969). Drug induced changes in free, labile and stable acetylcholine of guinea-pig brain. Biochem. Pharmac. 18: 1315-1324.

Bertels-Mefuws, M. M. and Polak, R. L. (1968). Influence of antimuscarinic substances on in vitro synthesis of acetylcholine by rat cerebral cortex. Br. J. Pharmac. Chemother. 33: 368-380.

BradLey, P. B. and ElKes, J. (1953). The effect of atropine, hyoscyamine, physostigmine and neostigmine on the electrical activity of the brain of the conscious cat. J. Physiol., Lond. 120:14P-15P.

Bradley, P. B., Dhawan, B. N. and Wolstencroft, J. H. (1966). Pharmacological properties of cholinoceptive neurones in the medulla and pons of the cat. J. Physiol., Lond. 183: 658-674.

Carruyo, L. P. and Domino, E. F. (1970). Serotonergic-cholinergic interactions in NREM-REM sleep. In: Congress of International Neuropharmacology, VII Congress abstracts, p. 76, Prague.

Celesia, G. G. and JASPER, H. H. (1966). Acetylcholine released from cerebral cortex in relation to state of activation. Neurology, Minneap. 16: 1053-1063.

CrossLand, J. (1961). Biologic estimation of acetylcholine. Meth. med. Res. 9: 125-129.

Crossland, J. and Slater, P. (1968). The effect of some drugs on the "free" and "bound" acetylcholine content of rat brain. Br.J. Pharmac. Chemother. 33: 42-47.

Davis, W. M., KING, W. T. and BABBINI, M. (1971). Physostigmine and pentobarbital: Biphasic interaction in mice. Archs int. Pharmacodyn. Thér. 192: 152-159.

Domino, E. F., YAmamoto, K. and Dren, A. T. (1968). Role of cholinergic mechanisms in states of wakefulness and sleep. In: Progress in Brain Research, Vol. 28. Anticholinergic Drugs and Brain Functions in Animals and Man (Bradley, P. B. and FinK, M., Eds.), pp. 113-133, Elsevier, Amsterdam. 
Everett, G. M. (1964). Pharmacological studies on tremorine. In: Proc. 2nd Int. Pharmac. Meeting (Trabucchi, E., Paoletti, R. and Canal, N., Eds.), Vol. 2, pp. 69-74, Macmillan, New York.

FeldBerG, W. (1945). Present views on the mode of action of acetylcholine in the central nervous system. Physiol. Rev. 25: 596-642.

Fischer, H. D., Westermann, K. and Oelssner, W. (1969). Regionale Verteilung von Azetylcholin im Rattenhirn und deren Beeinflussung durch Cholinomimetika und Cholinolytika. Acta biol. med. germ. 23: $181-188$.

Ilyutcienok, R. Yu. and Zinevicii, V. S. (1970). Short latency reticulocortical potentials: Effect of muscarinic anticholinergic drugs. Neuropharmacology 9: 433-440.

JASPER, H. H. and TESSIER, J. (1971). Acetylcholine liberation from cerebral cortex during paradoxical (REM) sleep. Science 172: 601-602.

Kalyanpur, S. G. and Prasad, C. R. (1967). Influence of atropine and physostigmine on pentobarbital sleeping time in mice. Archs int. Pharmacodyn. Thér. 170: 364-370.

Karczmar, A. G, Longo, V. G. and Scotti De Carolis, A. (1970). A pharmacological model of paradoxical sleep: the role of cholinergic and monoamine system. Physiol. Behav. 5: 175-182.

Koelle, G. B. (1970). Anticholinesterase agents. In: The Pharmacological Basis of Therapeutics (Goodman, L. S. and Gilman, A., Eds.), 4th Edition, Macmillan, New York.

Longo, V. G. and Silvestrini, B. (1957). Action of eserine and amphetamine on the electrical activity of the rabbit brain. J. Pharmac. exp. Ther. 120:160-170.

MacIntosh, F. C. and Oborin, P. E. (1953). Release of acetylcholine from intact cerebral cortex. XIX Int. Physiol. Congr. Abst. Commun. pp. 580-581.

Malpica, J. F., Jurupe, H. and CAmpos, H. A. (1970). Actions of reserpine and tyramine on the acetylcholine content of brainstem, heart and blood of the rat. Archs int. Pharmacodyn. Thér. 185: 13-19.

Megazzini, P., Bernardi, G. and Ballotti, P. (1965). Regional changes of the cholinergic system in the guinea-pig's brain after physostigmine. Experientia 21 : 406-408.

Mitchell, J. F. (1963). The spontaneous and evoked release of acetylcholine from the cerebral cortex. J. Physiol., Lond. 165: 98-116.

Murnaghan, M. F. (1958). The morphinized-eserinized leech muscle for assay of acetylcholine. Nature, Lond. $182: 317$.

Paton, W. D. M. and Perry, W. L. M. (1953). The relationship between depolarization and block in the cat's superior cervical ganglion. J. Physiol., Lond. 119: 43-57.

Pazzagli, A. and Pepeu, G. (1964). Amnesic properties of scopolamine and brain acetylcholine in the rat. Int. J. Neuropharmac. 4: 291-299.

Pepeu, G. and Mantegazzini, P. (1964). Midbrain hemisection: Effect on cortical acetylcholine in the cat. Science 145: 1069-1070.

Richter, D. and Crossland, J. (1949). Variation in acetylcholine content of the brain with physiological state. Am.J. Physiol. 159:247-255.

Rosecrans, J. A., Dren, A. T. and Domino, E. F. (1968). Effects of physostigmine on rat brain acetylcholine, acetylcholinesterase and conditioned pole jumping. Int. J. Neuropharmac. $7:$ 127-134.

Salmoiraghi, G. C. and Steiner, F. A. (1963). Acetylcholine sensitivity of cat's medullary neurons. J. Neurophysio!. 26: 581-597.

Shute, C. C. D. and Lewis, P. R. (1963). Cholinesterase-containing systems of the brain of the rat. Nature, Lond. 199: 1160-1164.

Shute, C. C. D. and LewIS, P. R. (1967). The ascending cholinergic reticular system: neocortical, olfactory and subcortical projections. Brain 90:497-520.

Stone, W. E. (1955). Acetylcholine in the brain. I. "Free", "bound" and total acetylcholine. Archs Biochem. Biophys. 59: 181-192.

Szerb, J. C. (1963). Nature of acetylcholine-like activity released from brain in vivo. Nature, Lond. 197: $1016-1017$.

Tobias, J. M., Lipton, M. A. and Lepinat, A. A. (1946). Effect of anesthetics and convulsants on brain acetylcholine content. Proc. Soc. exp. Biol. Med. 61: 51-54.

Yамамото, K. I. and Domino, E. F. (1967). Cholinergic agonist-antagonist interactions on neocortical and limbic EEG activation. Int. J. Neuropharmac, 6: 357-373. 